\title{
The Political Impact of the Festival - Biblical State-
}

ments

Georg Braulik*

(Wien)

\section{ABSTRACT}

\section{The Political Impact of the Festival - Biblical Statements}

Liturgy possesses a socio-critical potential which greatly surpasses political activism. It bypasses the systems of a "complex society", such as socialisation, communication and economics, through its factual logic which stands independent of faith. This political force is already developed by the feast on Sinai, to which Israel is lead out of Egypt (Ex 5:1-3). There, Israel receives the Torah, in order that its life as the people or community of Yahweh may be successful in the Promised Land. The community is to renew itself on occasion of the three pilgrimage festivals. For this purpose, Deuteronomy developed two basic types of popular liturgy within the scope of its theology of the people of God. The first is constituted by the passion commemoration of the passover (Dt 16:1-8). It aims at the social liberation of everyone in Israel, in commemorating their being lead out of Egyptian slavery. The second type is presented in the Feast of Weeks and the Feast of Tabernacles (16:9-12, 13-15). They initiate a fraternal society devoid of poverty, and already realise this in a realistic-symbolic way, through the communal meal of rejoicing in which all are to participate before Yahweh. According to this model, the eucharistic celebrative joy of the first Jerusalem congregation (Acts 2:44-46) reveals its community-changing force in the fact that "no poor were to be found any more" among the believers (Dt 15:4 in Acts 4:32-34).

\section{LITURGY IN TENSION BETWEEN CURRENT POLITICS AND ALIENATION FROM THE WORLD}

Let us recall the situation shortly before the break-up in Eastern Europe. At that time, the churches had become sanctuaries for demonstrators and pilgrims. Divine services, sermons, prayers for peace and all night prayers became politically explosive.

*Georg Braulik, professor in Old Testament (University of Vienna) visited South Africa as guest and research fellow of the departments Biblical Studies/Old Testament. 
The systems of power responded with truncheons, tear gas and arrests. During a brief period, public opinion all over the world was aware of the potential for social criticism inherent in liturgical celebrations. Obviously, many other factors contributed to the fall of the regimes. Today, however, the hopes which arose at that time of radical change have, for many people, given rise to deep and bitter disappointment. The negative aspects of the capitalist economic system are becoming more and more apparent. Yet precisely from this system, people had hoped for sheer miracles of humaneness and prosperity. As for the Church and its liturgy, there is the risk that in Eastern Europe too, the Church will become a religious subsystem in a complex society, as is already the case in Western Europe. Such a religious subsystem consists in a world of religious symbols, whose functions are strictly limited to the individual sphere and whose rituals concentrate primarily on turning-points in life. Such a religious subsystem has no influence on other subsystems, such as socialization, communication and the economic system. These systems all follow their own logic, independently of religious faith. It may be that our churches have long since aaccepted this role, for all they speak of the mission of Christians in the world. After all, what image of the Church, what programme for God's people - and that means God's society - do our eucharistic celebrations present?

This is why I propose to ask what political impact we may discover in the celebration of a festival if we understand it in the biblical sense. I shall ask this question against the background of, on the one hand a liturgical activism coloured by the politics of the day, on the other, a liturgy which has lost touch with the world and with society. As an Old Testament scholar, I take the material for my reflections from the writings of the Old Testament. However, I shall try to explore resemblances to the New Testament view as well as possible impulses for our present situation ${ }^{1}$.

\section{THE FESTIVAL AS ORIGIN OF A TRUE SOCIETY}

The reader of the Old Testament encounters the festival for the first time in the Book of Exodus. The immediate context is political. It is the passage where Mose and Aaron intercede by Pharaoh for the enslaved Israelites and say to him: "These are the words of the LORD the God of Israel. Let my people go so that they may keep my pilgrim feast in the wilderness". (Ex 5,1) This pilgrim feast is undoubtedly closely connected with a highly political act, the exodus from Egypt. But the liberation from oppression and exploitation in Egypt is not the only goal, not even the only political goal. For those who leave their old society and assemble at the foot of the 
mountain of God are made into the Old Testament Church through this very festival and receive God's law, his statutes for a new social order. Thus the festival - the "pilgrim feast" - is the origin of the true society. And there is something else, which is theologically decisive: Israel was in fact only to celebrate a feast for YHWH in the desert. This celebration was directed entirely towards God himself and took place in the desert, where all the essentials for human well-being were lacking. There is a kind of paradox here: those who, for the sake of God, leave Egypt and their old society for the desert receive from God, through his social order, the solution of their problems on how to live together in a humane fashion and structure their world, and they are led by God into a land flowing with milk and honey ${ }^{2}$. If, taking the Bible as one's foundation, one says something like that, the immediate answer tends to be: "That may have been so at the time of the exodus. But it is certainly not possible for the Church today. Unlike Israel, the Church does not constitute a people. And in any case, we cannot simply leave our country and go somewhere else". This, of course, is true.

But strictly speaking, it was true for Israel as well. From a certain point in its history, the people of Israel was not primarily ethnically defined, but defined as those who had faith in YHWH. From then on, Israel is a people in the sense that it is God's own society. The land of Israel, too - although of course it is also a stretch of land to be cultivated is theologically constituted. The land is never autonomous property and it is never a place of secular existence; it is the territory where God's social order is realized. That is why the exodus and the conquest and settlement are repeated later on in the history of Israel. Even when Israel is already living in Canaan and has begun to worship the gods of fertility and is changing into a society of slave owners, God according to the prophet Hosea leads them into the desert again. There is no need for any change of place: the social wrongs have made their own land into a desert. Even though Israel remains in the land, there has to be an exodus through which she can return to her first love. God again gives his people justice and right and blesses the land once more (Hos 2,16-25). I see no reason why something analogous should not hold for our Christian communities. But let us return to the festival and its most important political consequence, the renewal of society. Not only the exodus and the conquest and settlement, but also the assembly of the people at the mountain of God, where they hear the Torah, belong to canonical history and mark the future existence of Israel. Indeed, Israel must regularly return to this original situation through a ceremonial learning ritual ${ }^{3}$. In this way, she is reborn in the 
collective consciousness as the society of YHWH. The directions are found in Deuteronomy 31,10-13:

At the end of every seven years, at the appointed time for the year of remission, at the pilgrim feast of the Tabernacles, when all Israel comes to enter the presence of the LORD your God in the place which he will choose, you shall read this law publicly in the hearing of all Israel. Assemble the people, men, women and dependents, together with the aliens who live in your settlements, so that they may listen and learn to fear the LORD your God and observe all these laws with care. Their children, too, who do not know them, shall hear them and learn to fear the LORD your God.

This is the year of remission, in which every citizen has his debts remitted (Deut 15,1-3). In this way, there is a return to the egalitarian exodus generation. At the same time, the feast of Tabernacles is celebrated, and everyone is invited to eat, drink and rejoice in Jerusalem for seven days (Deut 16,13-15). In the middle of this fete, it happens: the deuteronomic Torah is recited and repeated in chorus by the thousands who are assembled. Hearing and repeating this text together gives birth to an inner fear of YHWH, to the tremor and the fascination which Israel first experienced during the theophany at the mountain of God. In consequence, Israel was to order her whole life in accordance with this divine secret (Deut 5,23-29). What this means is made clear by the ordinances of the deuteronomic social order. Thus YHWH's people, that is to say, God's society, is reborn in the festival. And something more happens: this society finds the purest image of itself in festival and celebration.

The Book of Deuteronomy is the first Old Testament document in which we find a certain systematic reflection on this matter. Its theory of the festival ${ }^{4}$, which is part of an extensive theology of the people, sets forth two main types of liturgy - of popular liturgy. One type is most apparent in the passion commemoration of the Passover, the other in the two harvest festivals, the feast of Weeks and the feast of Tabernacles. I propose to deal with this more in detail. To begin with, I shall sketch the historical background of the cultic legislation of Deuteronomy. In connection with this, I shall explain the religio-political setting of the three main festivals and describe their social consequences. When we are concerned with the society of Israel being renewed through the liturgy, I shall mainly refer synchronically to the final redaction of the book. 


\section{THE RELIGIO-POLITICAL AND SOCIAL DIMENSIONS OF THE DEUTERONOMIC SOCIAL REFORM}

\subsection{The Historical Background}

In the second part of the eighth and in the seventh centuries BC, the entire Ancient Orient was shattered by the military power of the neo-Assyrian empire and its victories, won in the name of the god Assur. The economic strength, the culture and especially the magnificent religious ceremonial of this empire profoundly shook the self-confidence of the vassal state of Judah and made its religious symbols seem obsolete. However, it was probably not merely through cultural pressure that the religious ideology of the new overlord became dominant. It appears that the Assyrian cults were officially introduced as well, particularly in Jerusalem. The traditional faith in YHWH must by then have lost much of its social credibility: this is made obvious by the unexpected attraction people felt for the indigenous Canaanite subcults. Their sudden rise in popularity is shown by archeological finds 5 . For instance, in several cities every second family possessed a clay figure of the goddess of fertility and the house cult seems to have centered round this figure. From the Book of Jeremiah, we know that the women of Jerusalem began to make currant cakes in honour of the queen of heaven and to pour out drink-offerings and that the men burnt incense on the roofs in honour of the stellar divinities or sacrificed their babies to Moloch in the valley of Hinnom (Jer 7 and 44). Through all these foreign patterns of thinking and acting, the emotional ties with Israel's authentic religious tradition and with her own values disappeared. YHWH lost his prestige even among simple people. The state of Judah was in danger of losing its identity as the people, as the society of YHWH. And then the book of the law was "discovered" in the Temple of Jerusalem during the reign of King Josiah, in 622 or 621 . Many exegetes identify this book with the oldest literary stratum of Deuteronomy, the original Deuteronomy. The original Deuteronomy was probably written by those circles in the ruling elite of Jerusalem who possessed the necessary juridical, literary and theological qualifications. Amongst other things, it probably already contained various laws regarding sacrifices and the social order, as well as a kind of festal calendar (Deut 16,1-17). The rubrics of this festal agenda determined the annual cycle of the three pilgrim feasts, for which the whole people was to assemble in Jerusalem, at that time the only legitimate sanctuary. These were the Passover and the two harvest festivals, the feast of Weeks and the feast of Tabernacles. 


\subsection{The Celebration of the Passover and the Social Liberation of Israel}

2 Kings 23 tells us that the treaty, or as we should say, the covenant through which King Josiah pledged himself and his people to observe the rediscovered deuteronomic law was crowned by a communal celebration of the Passover in the Temple of Jerusalem - as "this book of the covenant" that is, Deuteronomy - "prescribed". No such Passover had been kept since the days of the Judges ( $2 \mathrm{Kgs} 23,22$ ). What was then celebrated was in fact something new, although it was surrounded by the pathos of a renewal of an ancient custom. As King Josiah celebrated Passover for the first time, this was a politico-cultic act. It gave emphasis to the King's national liberation movement against the neo-Assyrian empire and at the same time it signified a refusal to depend on Egypt, at that time growing stronger. The introduction of the deuteronomic Passover was not, however, limited to this function in current politics. The act of introducing the celebration of Passover was thought of as revitalizing a ritual dating back to the tribal society of the time of the Judges. The Passover celebration was an excellent example of a liturgy of liberation, which made the people of God into an authentically redeemed and therefore liberating society from the very beginning of its history, the exodus from Egypt.

The Passover renders the exodus from slavery in Egypt present through a cult drama. I should like to elaborate on this. The deuteronomic festal calendar states that the festival of Passover is to be celebrated at the new moon of the spring month of Abib.

For at the new moon of Abib, the LORD your God brought you out of Egypt by night (Deut 16,11).

The text goes on

"For seven days you shall eat unleavened cakes, the bread of affliction. In urgent haste you came out of Egypt and thus as long as you live you shall commemorate the day of your coming out of Egypt" (Deut 16,3).

This constitutes the theological centre of the Passover agenda. The festival is characterized as a commemoration of suffering, which pledges the community to renew its life in accordance with its origins in the exodus from Egypt. In this ritual symbolism, the unleavened cakes commemorate the hurried flight into freedom. Furthermore, the mazzot are eaten together with the sacrified and prepared Passover animal. During this communal meal, the people experience unity among themselves and communio with their God. At the same time, the memory kept awake by the Passover night becomes the promise of a liberated society. For the purpose of the 
Passover liturgy is that you should commemorate the day of your coming out of Egypt as long as you live (Deut 16,3). The exodus, relived through cult symbols, is to determine everyday life.

That the cultic world of the Passover is meant to change the social consciousness of Israel, is made apparent by another law. During the following seven days, there must be no unleavened bread in the whole national territory (Deut 16,4). The unleavened cakes which are to be eaten on the way back from Jerusalem to the towns and villages no longer symbolize the hasty departure from Egypt, but the food of those who are still "under way". They interpret the return home as entering the land of promise. Although Israel has lived in her land for a long time, society is renewed at the yearly Passover through the grace of the exodus.

The deuteronomic law shows what this means in practice. This law develops the parenesis of the Passover: "that you shall commemorate the day of your coming out of Egypt as long as you live". There is no doubt that the Decalogue constitutes the pattern of the exodus ethic. The Decalogue is also bound up with liberation. In the prologue, YHWH introduces himself as the God who freed Israel from slavery in Egypt. The commandments which follow constitute YHWH's directions to his people on how to safeguard the freedom they had received so that it should not degenerate into a new form of oppression 6 . Hence anyone who worships other gods - first commandment - rejects not only YHWH, but also the prerequisites of a life in freedom. Or - third commandment - those who keep the sabbath practice freedom in an exemplary way. In the general rest from work, even those who are normally not free, male and female slaves and aliens, experience freedom (Deut 5,12-15). One could go through all the commandments in this way. The Decalogue constitutes a brief ethical formula on how to realize the freedom of the exodus. How important this formula was for the entire construction of Israelite society can be concluded from its literary "career" in Deuteronomy.

It was probably during one of the early revisions of the Josianic book of law that the Decalogue was put at the beginning of the "statutes and laws". In the final edition of Deuteronomy, the law code with its statutes is ordered according to the sequence of the ten commandments and constitutes a kind of commentary on them ${ }^{7}$.

The connection between the prologue of the Decalogue and the corpus of the ten commandments is further expounded in seven statutes: Deuteronomy 5,$15 ; 10,19 ; 15,15 ; 16,12 ; 23,8 ; 24,18.22$. The keyword is in most cases the verb "commemorate", also characteristic of the Passover. Anyone who is free and is living on his own property is to 
remember that he has been a slave and an alien in Egypt and he is therefore to give others their freedom in a specific manner. There is a factual connection between the Egypt motivation and the contents of the statutes, since we are always concerned with exigences made in favour of social fringe groups: slaves, aliens, orphans and widows. Thus a "fellow Hebrew", man or woman, who has sold himself or herself in payment of a debt is to be set free since you were slaves in Egypt and the LORD your God redeemed you (Deut 15,15).

Aliens, orphans and widows are allowed to glean in the fields, on the olive trees and in the vineyards.

"Remember that you were slaves in Egypt; that is why I command you to do this" (Deut 24,22).

To love the alien is to imitate the love of God. For YHWH "loves the alien who lives among you, giving him food and clothing. You must love the alien, for you once lived as aliens in Egypt" (Deut 10,19).

Finally, Israel is reminded of her experience in Egypt in a context where the liturgical legislation becomes socio-politically explosive. This happens where the participants in the feast of Weeks are enumerated (Deut 16,12). The reference to Egypt may, of course, have been suggested by the Passover, since 16,12 at least redactionally combines the feast of Weeks with the Passover parenesis in 16,3. However, the reference to Egypt has quite a different function in the text concerning the feast of Weeks. The Passover renders present the exodus from Egypt in order that it may have a liberating effect on social life after the festival. At the feast of Weeks, on the other hand, the exhortation to remember the slavery in Egypt has to do with what is to be done through the feast itself for those who are not free, that is, for those who have no property. Slaves, Levites, aliens, orphans and widows are to be socially emancipated and integrated through their participation in the feast (Deut 16,11f; compare this to the statute about sabbath rest in Deut 5,14f.). Let us take a closer look at the harvest festivals.

\subsection{The Harvest Festivals and Israel as a Fraternal Society with no Poor}

Like the Passover, the feast of Weeks and the feast of Tabernacles aim at social change. These two harvest festivals existed before Deuteronomy, but the deuteronomic liturgical reform gave them a clear religio-political edge. Archeological finds, but also some texts in Hosea and Jeremiah make it clear that the indigenous fertility cults had for some time known a fascinating renaissance. The deuteronomic ritual excluded everything that 
was incompatible with authentic faith in YHWH, for instance magicoecstatic and sexual union with the divinity in order to ensure fertility. That is why nothing is said about a communal cult meal in connection with either the feast of Weeks or the feast of Tabernacles. Yet probably the greatest fete of the year was held in connection with the harvest thanksgiving (cf Deut 14,22-2). Furthermore, in addition to the former agenda (Ex 34,18-23; 23,14-17), the directives for the festival explicitly exhort Israel to "rejoice before YHWH, your God" (Deut 16,11.14). In that particular context, this implies a confession that YHWH alone, not Baal or Ashera, has given the produce of fields and vineyards. The status confessionis, in view of the seductive alternatives surrounding Israel, is finally shown in the sacrifice of the best or first produce, probably placed at the altar of the Temple of Jerusalem at the feast of Tabernacles. Those who offered the sacrifice had to recite a short profession of faith especially created for this occasion, the so-called short historical credo (Deut 26,111), which relates the rich harvest to YHWH leading the Israelites out of Egypt and giving them the land8.

In spite of this, the deuteronomic cultic legislation was not mainly apologetic. It was a way of responding to the genuine needs manifested in the fertility cults. Deuteronomic legislation made the two harvest festivals into peak experiences of human joy and reshaped them socio-politically in accordance with the theology of the people. In contrast to the old cultic calendar (Ex 34,18-23; 23,14-17; cf Deut 16,16f), the festivals now became expressions of socialization and of the Israelite world-view. Since the primitive Christian community of Jerusalem as depicted in the Acts of the Apostles was later to resume the deuteronomic festival tradition, I should like to describe this model at some length.

In contrast to the Passover, where everything was regulated in detail, the feast of Weeks and the feast of Tabernacles remain to a large extent open as far as ritual is concerned. True, they have to be celebrated in the Temple of Jerusalem. But even the time of the celebration depends on the harvest, which is brought in at different times depending on the year and on the locality. Every family is to bring thanks because of their own personal experience of YHWHs blessing. Liturgy is here understood entirely in relation to human beings and their situation. For only those who really know that they have received a gift are able to render thanks (or, as we should say, to participate in the eucharist), and to rejoice before God. Eating, drinking and dancing belong to this rejoicing. The Hebrew word hagag, which we translate "to celebrate a feast" originally meant "to turn round in a circle, to dance". This rejoicing also includes everything which 
makes the seven-day-long feast of Tabernacles into "your feast" (Deut $16,14)$ during which one tenth of the yearly produce is "blued" and everybody "keeps the feast with joy" (Deut 16,15). At the same time, this rejoicing before God has a mystical dimension. The purest form of rejoicing before God is not found where sacrifices are brought, but in the sincerity of the prayers which are said afterwards and in the joy arising from the communal feast after the sacrifice has been brought. Whereas Deuteronomy speaks of rejoicing before God, the New Testament says "in Christ" or "in the Holy Spirit". Joy is the keyword of the deuteronomic festival theory. The deuteronomic Torah knows no other joy. This joy belongs to the liturgical celebration. In this context, the groups who take part in the sacrificial meals and are exhorted to rejoice become important.

The festival order, which otherwise gives but few ritual prescriptions, determines in detail who is to be invited:

"You shall rejoice in the feast with your sons and daughters, your male and female slaves, the Levites who live in your settlements, and the aliens, orphans and widows among you" (Deut 16,11; cf 16,14).

This list of participants aims at being complete. It should not, however, be interpreted casuistically, as though everyone had to leave their houses and farms and go to Jerusalem. The list affirms a theological goal: the festival is to break down the class barriers and to unite the whole people in rejoicing. Hence the unity of the festival community is constituted by the families and by the classic fringe groups of Ancient Oriental society. The list of participants mentions the members of an Israelite house. Male and female slaves also belong to the house. The fathers and brothers are not mentioned. But they have their own families, so the law addresses them directly. The Levites, the aliens, the orphans and the widows, that is, Israelites and non-Israelites without property, are to be invited. When everything is explained in such detail, one is all the more struck by the fact that the list does not mention "your wife". This means either that the free woman and housewife is also included in the "you" of the text, or - this is the second possibility - that while the whole family and all the servants leave for the pilgrimage and the rejoicing in Jerusalem, she alone is to stay at home in order to guard the house and do the work. The second possibility is scarcely credible. (This is also the case for the sabbath: the housewife and mother is the only member of the family who is not mentioned in Deut 5,14). Certainly one may assume that someone has to stay at home. But there is no reason to suppose that this is the specific task of the housewife. Obviously, then, free women are included in the "you" of the text. Indeed, we must go one step further. If 
the "you" intends both the free man and his wife, then this is also true of the preceding statute:

"you shall keep the pilgrim feast of Weeks to the LORD your God and offer a freewill offering ..." (Deut 16,10).

This means that both men and women are allowed to bring sacrifices. The same goes for the other laws concerning sacrifices and festivals. They, too, use inclusive speech and textpragmatically include both men and women, when they speak of a "you" bringing a sacrifice. We should realize, however, that according to Deuteronomy, bringing sacrifices is not the task of the priests, but of all Israelites. The priests certainly have a "right" to a certain sacrificial tariff from "those of the people who offer a sacrifice" (Deut 18,3). In other words, it is the people who offers a sacrifice. The priests are not paid for offering sacrifices. Their tasks consist in services in the domain of the Torah, for instance giving sentence in the main court of justice (Deut 17,9-12). Offering sacrifices remained the business of laypeople. However, the deuteronomic legislation was probably the first to allow women access to the altar. This is only done implicitly and with great prudence. Yet the intention of the legislation is clear. A woman is just as qualified as a man to offer a sacrifice. This is not to say, of course, that she had to do the whole ritual slaughtering alone. When an animal was killed as a sacrifice, there were normally several people to do the killing. This is sure to have been the case in the Temple, where the whole family as well as the servants participated in the sacrifice. What is decisive is that a woman could count as the person who formally brought the sacrifice by sprinkling the altar with blood (Deut 12,27 ) or by placing the basket with the "first fruits of all the produce of the soil" before the altar (Deut 26,1-10; the later interpolation of 26,4 is different)9.

We do not know to what extent the equality of women in the liturgical domain became a reality or whether it remained a utopic programme. At any rate, the deuteronomic social plan in the current legislation assumes that there can be a community of brothers and sisters in the liturgical celebrations. This is why both the liberation which is celebrated in the Passover and the fraternal life which is realized in the festival become principles of socio-political action. The liturgies of the Passover and of the festivals illuminate those aspects of social life which cannot be controlled through legislation and sanctions, but demand an ethic of personal responsibility and therefore have to be motivated.

The fraternal ethic ${ }^{10}$ anticipated by the festivals also concerns women; according to Deuteronomy, women are explicitly "brothers" $(15,12)$, and a series of laws show that there was a tendency towards the 
social emancipation of women. But above all, fraternity was to be practised towards those who participated in the feasts together with the Israelite families: the Levites, the aliens, the orphans and the widows (to a certain extent also towards the slaves). These people are usually interpreted as "the poor"11. Orphans and widows, for instance, belonged to the classic personae miserae in the whole Ancient Orient. But in Deuteronomy, they are obviously not "the poor". None of these groups of the population is thus described. Levites, aliens, orphans and widows for different reasons possess no fields of their own from which they could get a living and must therefore be provided for. Hence Deuteronomy has created a system of social security. Like our modern social security, this has nothing to do with "charity", it is something people have a right to. The most interesting law is the one about the tithes of every third year (Deut 14,28f.). It stipulates that, every third year, the tithes are not to be brought to the central sanctuary, but are to be stored up in the towns and villages for the Levites, the aliens, the orphans and the widows, that they "may come and eat their fill". Thus the lower social margin, present everywhere else in the Ancient Orient, is eliminated. However, in procuring what is necessary for these social groups, the legislation was not concerned with material goods alone. The tithes, which every third year were not delivered to the Temple were nevertheless brought in relation with the liturgical centre, the Temple of Jerusalem, through a subsequent prayer (Deut 26,12-15).

Indigence is not caused only by lack of land. People can become poor in other ways, through various types of misfortune. If a society without poor classes is to be created, as the deuteronomic programme demands - "in fact there should be no poor among you" (Deut 15,4) - no impoverished classes must be allowed to be created. Therefore those who have lost their property must receive assistance immediately. All Israelites, men and women, are exhorted to abolish poverty around them by giving from what they possess:

"The poor will always be with you in the land, and for that reason I command you to be open-handed with your countrymen, both poor and distressed, in your own land" (Deut 15,11).

The fraternal way of life, then, is to abolish all those contrasts in society which produce rich and poor classes. The fraternal way of life supersedes every "right" and makes all Israel into a place where everyone is to behave as one normally behaves only within a family living in the same house.

The festival is the place where this world is programmed and symbolically realized ${ }^{12}$. Therefore Deuteronomy never uses the term "brother" in 
liturgical ordinances. When the families who have been blessed with the produce of fields and vineyards assemble to celebrate their festival in the Temple of Jerusalem and there experience the presence of YHWH in the sacrificial meal and in the joy, and so the peak points of Israelite life are reached, the groups without property participate in this happiness. All are one, there are no longer any social distinctions. Everyone is full of joy. At this moment, they are "before God". At no other time or place is Israel more perfectly herself. When this liturgical unity has been applied to the entire social reality of Israel, the festival has achieved its political goal.

The Acts of the Apostles explicitly refer to Deuteronomy in one of the decisive characterizations of the first Christian community in Jerusalem:

"The whole body of believers was united in heart and soul. Not a man among them claimed any of his possessions as his own, but everything was held in common ... They were all held in high esteem, for they had never a needy person among them" (Acts 4,32-34).

In this context, we are not concerned with the literary genre of this summary. What is affirmed is: Although before the arrival of the Messiah, Israel had never entirely followed the deuteronomic social legislation, the people of God assembled by Jesus followed it after receiving the Holy Spirit at the feast of Weeks. Here, too, the inspiration comes from the liturgy:

"All whose faith had drawn them together held everything in common: they would sell their property and possessions and make a general distribution as the need of each required. With one mind, they kept up their daily attendance at the temple, and, breaking bread in private houses, shared their meals with unaffected joy" (Acts 2,44-46).

In the communal meal, the eucharistic joy springs forth. This joy causes what Deuteronomy was the first to aim at: the political impact of the festival gives rise to a society of sisters and brothers in which there are no poor.

\section{NOTES:}

1 Cf G Braulik, "Eucharistie - Fest der Gemeinde. Bibeltheologische Uberlegungen", in Ordensnachrichten 23 (1984), 127-138.

$2 \mathrm{~N}$ Lohfink, Die richtige Gesellschaft, in: Kirchenträume. Reden gegen den Trend, Freiburg i.B. ${ }^{51982, ~ 64-90, ~} 84$.

3 N Lohfink, Der Glaube und die nächste Generation. Das Gottesvolk der Bibel als Lerngemeinshcaft, in: Das Jüdische am Christentum. Die verlorene Dimension, Freiburg i.B. 1987, 144-166 and 260-263; 158 f. 
4 G Braulik, Leidensgedächtnisfeier and Freudenfest. "Volksliturgie" nach dem deuteronomischen Festkalender (Dtn 16,1-17), in: Studien zur Theologie des Deuteronomiums (Stuttgarter Biblische Aufsatzbände 2), Stuttgart 1988, 95-121; G Braulik, Die Freude des Festes. Das Kultverständnis des Deuteronomiums die älteste biblische Festtheorie, ibid. 161-218. For other Old Testament cultic theologies, for instance those of the priestly code or of the Pentateuch redaction, see P Weimar, Kult und Fest. Aspekte eines Kultverständnisses im Pentateuch, in: K Richter (ed) Liturgie - ein vergessenes Thema der Theologie? (Ouaestiones disputatae 107), Freiburg i.B. 1986, 76-83 (contains references to further reading).

5 See G Braulik, Die Ablehnung der Göttin Ashera in Israel. War sie erst deuteronomistisch, diente sie der Unterdrückung der Frauen?, in: Studien zum Buch Deuteronomium (Stuttgarter biblische Aufsatzbände 24), Stuttgart 1997, 81-118.

6 See F Crüsemann, Bewahrung der Freiheit. Das Thema des Dekalogs in sozialgeschichtlicher Perspektive (Kaiser Traktate 78), Munich 1983.

7 G Braulik, Die deuteronomischen Gesetze und der Dekalog. Studien zum Aufbau von Deuteronomium 12-26 (Stuttgarter Bibelstudien 145), Stuttgart 1991.

8 G Braulik, Sage, was du glaubst. Das älteste Credo der Bibel - Impuls in neuester Zeit, Stuttgart 1979.

9 G Braulik, Haben in Israel auch Frauen geopfert? Beobachtungen am Deuteronomium, in: K Lüthi/S Kreuzer (ed), Zur Aktualität des Alten Testaments. Festschrift G Sauer, Frankfurt/M 1991.

10 See L Perlitt, “Ein einzig Volk von Brüdern”. Zur deuteronomischen Herkunft der biblischen Bezeichnung "Bruder", in: Deuteronomium-Studien (Forschungen zum Alten Testament 8), Tübingen 1994, 50-73.

11 For what follows, see N Lohfink, Das deuteronomische Gesetz in der Endgestalt - Entwurf einer Gesellschaft ohne marginale Gruppen, in: Studien zum Deuteronomium und zur deuteronomistischen Literatur III (Stuttgarter biblische Aufsatzbände 20), Stuttgart 1995, 205-218.

12 N Lohfink, Opferzentralisation, Säkularisierungsthese und mimetische Theorie, in: Studien (wie Anm. 11), 219-260, 240-244. 